\title{
KEMAMPUAN KOMUNIKASI MATEMATIS SISWA DITINJAU DARI INTELLIGENCE QUOTIENT (IQ) PADA SISWA SMA NEGERI 6 SURAKARTA
}

\author{
Wahyumiarti $^{1}$, Tri Atmojo Kusmayadi ${ }^{2}$ Riyadi $^{3}$ \\ ${ }^{1,2,3}$ Prodi Magister Pendidikan Matematika, FKIP Universitas Sebelas Maret Surakarta
}

\begin{abstract}
This study aims to analyze the ability of mathematical communication at students with a high, medium, and low IQ in grade XI MIA of State Senior High School 6 Surakarta in answering math questions. The subjects were 6 students that two students with high IQ, 2 students with medium IQ, and 2 students with low IQ. Techniques of data collection used documents and archives, a written test and an interview. Data analysis techniques used are data reduction, data presentation, and conclusion. The results of research showed that: (1) students with high IQ: in the mathematical written communication skills, students were able to create situations and proper solutions using the diagram, the students were also able to translate the ideas contained in the diagram with their own words in the form of detailed and structured information, and able to express ideas and opinions with good reason. In the mathematical verbal communication skills, the students were able to provide some information and the situation in the form of their own language, students were also able to express the right opinions to answer and respond questions in the form of a convincing argument and be able to make correct conclusions with emphatic pronunciation; (2) students with medium IQ: in the mathematical written communication skills, students were able to create situations and proper solutions to depict diagrams and adding several full details, students were also able to translate the ideas contained in the diagram with their own words which arranged in structured by providing some information, ideas and information, but students gave a brief opinion in giving reasons about diagram. In the mathematical verbal communication skills, the students were able to provide some information and situation into their own language forms in detail, complete, and structured, students were also able to give an opinion clearly and convincingly, in addition the student also gave some suggestions, and able to respond to questions in the form convincing argument and students were able to make the right conclusions but short explicitly; (3) students with medium IQ: in the mathematical written communication skills, students were able to create situations and appropriate solutions to describe the diagram and added some description, students were also able to translate the information contained in the diagram with their own sentences with ideas and information relating to the matter. In the mathematical verbal communication skills, students were able to give some brief information in the form of their own language, students were able to express opinions and suggestions but there is still less precise answer, the student was not able to properly respond to questions when giving an answer, but the students were able to make some conclusions short with a convincing argument.
\end{abstract}

Keywords: Mathematical Communication, Math Questions, Intelligence Quotient.

\section{PENDAHULUAN}

Matematika merupakan salah satu mata pelajaran yang diajarkan pada siswa dari tingkat sekolah dasar hingga sekolah menengah. Matematika merupakan suatu mata pelajaran yang terstruktur, terorganisasi, dan berjenjang, artinya antara materi yang satu dengan materi yang lainnya saling berkaitan. Matematika tidak hanya sekedar alat bantu berpikir dalam menjawab soal, namun matematika adalah bahasa untuk mengomunikasikan gagasan secara praktis, efisien, dan sistematis. Dalam pembelajaran 
matematika, seorang siswa yang sudah mempunyai kemampuan pemahaman matematis dituntut juga untuk bisa mengkomunikasikannya, agar pemahamannya tersebut bisa dimengerti oleh orang lain. Hal ini juga didukung oleh Depdiknas (2006) bahwa salah satu tujuan adanya pelajaran matematika agar peserta didik dapat mengomunikasikan gagasan untuk memperjelas keadaan atau masalah.

Komunikasi matematis adalah cara bagi siswa untuk mengomunikasikan ide-ide, strategi maupun solusi matematika baik secara tertulis maupun lisan. Komunikasi adalah bagian penting dari matematika dan pendidikan matematika. Sedangkan, kemampuan komunikasi matematis dalam menjawab soal menurut National Council of Teachers of Mathematics (2000: 348) dapat dilihat ketika siswa menganalisis dan menilai pemikiran dan strategi matematis orang lain dan menggunakan bahasa matematika untuk menyatakan ide matematika dengan tepat.

Clark (2005: 5) menyatakan bahwa "Math is communication. You have to be able to communicate the concepts. You have to be able to communicate your thinking. Numbers are not enough for any good mathematician. You have to prove. You have to convince". Hal ini menunjukkan bahwa siswa harus mampu menyampaikan isi pemikirannya tentang masalah matematika, bukan hanya dalam hal menghitung tapi juga bagaimana mengkomunikasikan matematika tersebut baik secara lisan maupun tulisan. Selain itu Hirschfeld (2008: 4) juga berpendapat bahwa dengan adanya komunikasi siswa mengenai ide dan apa yang mereka pikirkan, guru bisa mengerti apa yang diketahui dan apa yang tidak diketahui oleh siswa. Hal ini didukung oleh hasil penelitian Borasi and Rose dalam Kosko and Wilkins (2010: 81) yaitu "Students who write to explain or describe solution strategies experience an improvement in their problem solving skills". Seseorang yang menulis untuk menjelaskan atau mendeskripsikan strategi solusi mengalami peningkatan keterampilan dalam menyelesaikan masalah. Menurut Jacobs (2002: 380-381) komunikasi ide - ide matematika dapat dilihat melalui lima aspek yaitu aspek representasi, aspek mendengar, aspek membaca, aspek diskusi, dan aspek menulis.

Pentingnya komunikasi membuat beberapa ahli melakukan riset tentang komunikasi matematis. Menurut riset Bergeson dalam penelitian Gusni (2006: 24) mengemukakan bahwa siswa sulit mengomunikasikan informasi visual terutama dalam mengomunikasikan sebuah lingkungan tiga dimensi (misalnya, sebuah bangunan terbuat dari balok kecil) melalui alat dua dimensi (misalnya, kertas dan pensil) atau sebaliknya.

Penelitian yang dilakukan oleh Qohar (2013: 45) menyatakan bahwa dalam suatu diskusi yang dilakukan peneliti dengan beberapa guru SMP terungkap bahwa siswa masih kurang baik dalam melakukan komunikasi, baik komunikasi melalui lisan atau tulisan. Siswa kesulitan untuk mengungkapkan pendapatnya, walaupun sebenarnya ide dan 
gagasan sudah ada di pikiran mereka. Guru menduga bahwa siswa takut salah dalam mengungkapkan gagasan-gagasannya, di samping itu siswa juga kurang terbiasa dengan mengkomunikasikan gagasannya secara lisan. Bergqvist and Osterholm (2012: 71) menyatakan bahwa siswa di kelas-kelas yang lebih rendah membutuhkan bantuan dari guru untuk berbagi ide-ide matematika terhadap satu sama lain dengan cara yang cukup jelas bagi siswa lainnya untuk saling memahami. Beberapa penelitian juga menunjukkan bahwa setiap siswa memiliki perbedaan mengenai kemampuan komunikasi matematis dalam menjawab soal matematika. Salah satunya penelitian yang dilakukan oleh Pratiwi (2013) mengenai kemampuan komunikasi matematis siswa yang ditinjau dari gaya kognitif, menunjukkan bahwa siswa yang memiliki gaya kognitif FD dan FI memenuhi semua indikator kemampuan komunikasi matematis yang telah dirumuskan, tetapi siswa dengan gaya kognitif FI mencukupi semua syarat komunikasi matematis dengan baik sedangkan siswa dengan gaya kognitif FD masih kurang dalam menganalisis informasi pada soal secara lisan.

Terkait dengan hal tersebut, setiap siswa memiliki cara yang berbeda dalam mengomunikasikan ide-ide penyelesaian soal, strategi maupun solusi matematika baik secara tertulis maupun lisan. Perbedaan ini dapat dilihat dari berbagai aspek, salah satunya dari kecerdasan intelektual atau yang dikenal dengan IQ. Kecerdasan ini tentunya berpengaruh terhadap bagaimana siswa tersebut berpikir, mengolah informasi dan mendefinisikan setiap permasalahan matematika. Kecerdasan ialah istilah umum yang digunakan untuk menjelaskan sifat pikiran yang mencakup sejumlah kemampuan, seperti kemampuan menalar, merencanakan, menjawab soal, berpikir abstrak, memahami gagasan, menggunakan bahasa, dan belajar. Menurut Alim Sumarno dalam Suparlan (2013), orang seringkali menyamakan arti intelegensi dengan IQ, padahal kedua istilah ini mempunyai perbedaan arti yang sangat mendasar. IQ atau singkatan dari Intelligence Quotient, adalah skor yang diperoleh dari sebuah alat tes kecerdasan. Dengan demikian, IQ hanya memberikan sedikit indikasi mengenai taraf kecerdasan seseorang dan tidak menggambarkan kecerdasan seseorang secara keseluruhan.

Berdasarkan penelitian-penelitian mengenai kemampuan komunikasi matematis siswa, membuat peneliti ingin mengetahui bagaimana kemampuan komunikasi matematis siswa dalam menyelesaikan soal matematika. Penelitian ini akan memberikan hasil yang lebih spesifik apabila subjek penelitian juga dikelompokkan, jadi peneliti meninjau terlebih dahulu skor IQ siswa. Selanjutnya peneliti akan menganalisis kemampuan komunikasi matematis siswa dalam menjawab soal matematika pada materi statistika. 


\section{METODE PENELITIAN}

Jenis penelitian ini adalah penelitian kualitatif eksploratif yang bertujuan untuk menganalisis kemampuan komunikasi matematis siswa dalam menyelesaikan soal matematika ditinjau dari masing-masing tingkatan IQ. Pemilihan subjek penelitian menggunakan teknik snowball sampling dengan prosedur awal pemilihan subjek penelitian yaitu memilih siswa yang telah mengikuti tes IQ dan memperoleh skor IQ berdasarkan aturan pengkategorian skor IQ. Selanjutnya dilakukan tes tertulis dan wawancara terhadap masing-masing subjek, kemudian hasil tes tersebut dianalisis. Jika hasil analisis subjek sebelumnya menunjukkan bahwa data yang diberikan belum lengkap maka peneliti mencari subjek lain yang dapat melengkapi data tersebut. Apabila data penelitian dari subjek kedua belum memberikan data yang lengkap, maka peneliti mencari sumber data lain dari subjek ketiga, keempat dan seterusnya. Pemilihan subjek akan berhenti apabila data sudah jenuh. Dari proses tersebut diperoleh subjek dalam penelitian ini 6 siswa yaitu 2 siswa dengan IQ tinggi, 2 siswa dengan IQ sedang, dan 2 siswa dengan IQ rendah.

Teknik pengumpulan data dilakukan dengan mengkaji dokumen dan arsip, melakukan tes tertulis, dan wawancara. Instrumen penelitian terdiri dari instrumen utama dan instrumen bantu yang telah divalidasi oleh tiga orang validator. Instrumen utama adalah peneliti sendiri, sedangkan instrumen bantu terdiri dari instrumen tes tertulis dan instrumen pedoman wawancara. Validitas data menggunakan triangulasi waktu. Teknik analisis data yang digunakan yaitu reduksi data, penyajian data, dan penarikan kesimpulan.

\section{HASIL PENELITIAN DAN PEMBAHASAN}

Kemampuan komunikasi matematis pada siswa yang memiliki IQ tinggi cukup baik dan memenuhi semua indikator komunikasi matematis, baik itu komunikasi matematis tertulis maupun komunikasi matematis lisan. Hal ini menunjukkan bahwa subjek dengan IQ tinggi mampu mengekspresikan ide-ide mereka untuk menjawab pertanyaan mengenai matematika secara tertulis maupun secara lisan.

Indikator kemampuan komunikasi matematis tertulis pada penelitian ini adalah menggambarkan situasi dan solusi menggunakan gambar atau grafik dengan tepat, menggunakan representasi menyeluruh untuk menyatakan suatu konsep matematika, membuat situasi matematika dengan menyediakan ide dan keterangan dalam bentuk tertulis. Pada indikator pertama, subjek mampu menggambarkan dengan baik sebuah diagram disertai dengan keterangan untuk melengkapi diagram. Kemampuan subjek menggambarkan data pada soal ke dalam bentuk suatu penyajian baru yaitu diagram garis 
dan diagram lingkaran menunjukkan bahwa subjek mampu mengomunikasikan ide ataupun gagasan yang terdapat dalam pikirannya untuk menyajikan data tersebut secara tertulis. Hal ini sesuai dengan pendapat yang dikemukakan oleh Jacobs (2002: 380-381) bahwa salah satu aspek kemampuan komunikasi matematis adalah representasi yaitu penerjemahan suatu ke dalam bentuk baru. Selanjutnya pada indikator kedua, subjek mampu menerjemahkan atau menceritakan kembali isi data pada diagram ke dalam bentuk kalimat yang disusun secara terstruktur. Subjek berusaha mengeluarkan seluruh gagasannya dan menuangkan ide tersebut ke dalam bentuk tulisan yang rinci berupa poinpoin informasi yang diperoleh dari data pada diagram. Pernyataan-pernyataan yang diungkapkan oleh subjek menunjukkan bahwa subjek mampu menyusun kalimat dengan baik sehingga tersusunlah beberapa informasi yang dapat mewakili data tersebut. Pada indikator ketiga, subjek juga mampu membuat situasi matematika dengan baik melalui keterangan-keterangan yang ditulis saat membuat langkah penyelesaian untuk menggambarkan diagram lingkaran. Langkah-langkah tersebut disusun secara terstruktur mulai dari awal sampai akhir sehingga diperoleh gambar diagram yang mewakili data pada tabel. Selain itu, subjek juga memberikan ide untuk menjawab pertanyaan terkait dengan konsep pengunaan diagram dengan baik. Pernyataan Borasi dan Rose dalam Kosko dan Wilkins (2010: 81) sesuai dengan kemampuan komunikasi matematis subjek dengan IQ tinggi yaitu seseorang yang menulis untuk menjelaskan atau mendeskripsikan strategi solusi mengalami peningkatan keterampilan dalam menyelesaikan masalah.

Kemampuan komunikasi matematis lisan pada subjek juga menunjukkan bahwa subjek memenuhi seluruh indikator yaitu menjelaskan ide, situasi, dan relasi matematika secara lisan dengan gambar atau grafik untuk menjawab pertanyaan pada soal, memberikan saran atau pendapat untuk menjawab pertanyaan yang diajukan, merespon suatu pertanyaan mengenai konsep dalam bentuk argumen yang meyakinkan. Pada indikator pertama, subjek mampu mengomunikasikan jawabannya berupa informasiinformasi yang diperoleh pada diagram yang disajikan pada soal. Subjek memperhatikan diagram dengan baik kemudian menyampaikan jawaban tersebut secara cermat dan rinci. Seluruh informasi, baik informasi yang langsung terlihat pada diagram maupun informasi yang tersirat, disampaikan dengan baik oleh subjek. Namun pada salah satu subjek yang diteliti, informasi yang disampaikan cukup singkat dan padat. Subjek hanya menyebutkan poin-poin tertentu tanpa memberi pengembangan kalimat untuk memperluas jawaban, tetapi informasi yang disampaikan subjek mampu mewakili data yang tersaji pada diagram. Selanjutnya pada indikator kedua, subjek mampu memberikan pendapatnya saat dilontarkan beberapa pertanyaan oleh peneliti. Pendapat yang disampaikan oleh subjek dapat diterima dan dipahami dengan baik melalui penjelasan yang cukup baik oleh 
subjek. Namun, saat peneliti meminta saran kepada subjek terkait dengan diagram tersebut, tidak satu pun dari subjek dengan IQ tinggi yang mampu mengeluarkan pendapatnya. Indikator ketiga pada kemampuan komunikasi lisan dipenuhi dengan baik oleh subjek. Hal ini terlihat dari respon subjek saat menjawab pertanyaan yang berkaitan dengan indikator secara langsung. Subjek menjawab dengan pasti dan yakin tanpa ada keraguan dalam penyampaiannya. Hal ini sesuai dengan indikator komunikasi matematis lisan yang dikemukakan oleh Djumhur dalam Jupri, dkk (2007) yaitu merespon suatu pertanyaan atau persoalan dalam bentuk argumen yang meyakinkan. Begitu juga saat peneliti meminta subjek untuk memberikan kesimpulan di akhir wawancara, subjek membuat kesimpulan benar dan lengkap yang merangkum seluruh pertanyaan sebelumnya. Subjek mampu memberi kesimpulan yang disusun dengan baik dalam suatu argumen yang meyakinkan.

Kemampuan komunikasi matematis pada siswa yang memiliki IQ sedang cukup baik dan memenuhi semua indikator komunikasi matematis, baik itu komunikasi matematis tertulis maupun komunikasi matematis lisan. Hal ini menunjukkan bahwa subjek dengan IQ sedang mampu mengekspresikan ide-ide mereka untuk menjawab pertanyaan mengenai matematika secara tertulis maupun secara lisan sesuai dengan pernyataan Clark (2005: 5) bahwa siswa harus mampu menyampaikan isi pemikirannya tentang masalah matematika, bukan hanya dalam hal menghitung tapi juga bagaimana mengomunikasikan matematika tersebut baik secara lisan maupun tulisan. Pada indikator pertama, subjek mampu menggambarkan dengan sangat baik dan jelas sebuah diagram disertai dengan keterangan untuk melengkapi diagram. Keterangan pada diagram yang dibuat oleh subjek dengan IQ sedang lebih lengkap dari pada keterangan yang dibuat oleh subjek dengan IQ tinggi. Subjek memberi tambahan keterangan yang membuat gambar diagram tersebut mudah untuk dipahami. Kemampuan subjek menggambarkan data pada soal ke dalam bentuk suatu penyajian baru yaitu diagram garis dan diagram lingkaran menunjukkan bahwa subjek mampu mengomunikasikan ide ataupun gagasan yang terdapat dalam pikirannya untuk menyajikan data tersebut secara tertulis. Kemampuan yang baik dalam menyampaikan apa yang terdapat dalam pikiran mengakibatkan orang lain bisa dengan mudah memahami ide yang dimiliki subjek. Selanjutnya pada indikator kedua, subjek mampu menerjemahkan atau menceritakan kembali isi data pada diagram ke dalam bentuk kalimat yang disusun secara terstruktur. Subjek berusaha mengeluarkan seluruh gagasannya dan menuangkan ide tersebut ke dalam bentuk tulisan yang rinci berupa poinpoin informasi yang diperoleh dari data pada diagram. Pernyataan-pernyataan yang diungkapkan oleh subjek menunjukkan bahwa subjek mampu menyusun kalimat dengan baik sehingga tersusunlah beberapa informasi yang dapat mewakilkan data tersebut. Pada 
indikator ketiga, subjek juga mampu membuat situasi matematika dengan baik melalui keterangan-keterangan yang ditulis saat membuat langkah penyelesaian untuk menggambarkan diagram lingkaran. Langkah-langkah tersebut disusun secara terstruktur mulai dari awal sampai akhir sehingga diperoleh gambar diagram yang mewakili data pada tabel. Selain itu, subjek juga memberikan ide untuk menjawab pertanyaan terkait dengan konsep penggunaan diagram, namun jawaban yang disampaikan subjek terlalu singkat jika dibandingkan dengan subjek dengan IQ tinggi. Hal ini disebabkan oleh kemampuan pemahaman materi konsep pelajaran yang dimiliki oleh subjek dengan IQ sedang masih berada dibawah subjek dengan IQ tinggi.

Kemampuan komunikasi matematis lisan pada subjek juga menunjukkan bahwa subjek memenuhi seluruh indikator komunikasi matematis lisan. Pada indikator pertama, subjek mampu memberikan sejumlah informasi dan situasi yang terdapat pada diagram ke dalam bentuk bahasanya sendiri. Subjek menyampaikan informasi yang diperolehnya secara rinci, lengkap dan terstruktur. Subjek juga menganalisis diagram tersebut dengan baik sehingga diperoleh ide dan situasi yang berkaitan dengan diagram. Selanjutnya pada indikator kedua, subjek mampu memberikan pendapatnya secara tegas dan yakin saat dilontarkan beberapa pertanyaan oleh peneliti. Pendapat yang disampaikan oleh subjek dapat diterima dan dipahami dengan baik melalui penjelasan yang cukup baik oleh subjek. Selain itu, subjek juga mampu memberikan saran untuk melengkapi diagram pada soal. Subjek mengemukakan idenya mengenai beberapa keterangan yang perlu ditambahkan pada diagram sehingga menghasilkan diagram yang lengkap dan lebih jelas daripada sebelumnya. Hal ini menunjukkan bahwa subjek dengan IQ sedang lebih memenuhi indikator kemampuan komunikasi matematis lisan dibandingkan dengan subjek dengan IQ tinggi, berbeda dengan hasil penelitian Suparlan (2013) yang menyimpulkan bahwa siswa-siswa pada semua kelompok kategori IQ, baik tinggi, sedang, maupun rendah mempunyai prestasi belajar yang sama. Indikator ketiga pada kemampuan komunikasi lisan juga dipenuhi dengan baik oleh subjek. Hal ini terlihat dari respon subjek saat menjawab pertanyaan yang berkaitan dengan indikator secara langsung. Subjek menjawab dengan pasti dan yakin tanpa ada keraguan dalam penyampaiannya. Begitu juga saat peneliti meminta subjek untuk memberikan kesimpulan di akhir wawancara, subjek mampu memberi kesimpulan yang disusun dengan baik dalam suatu argumen yang meyakinkan. Namun terdapat sedikit kekurangan yaitu kesimpulan yang disampaikan oleh subjek dengan IQ sedang cenderung lebih singkat jika dibandingkan dengan kesimpulan yang dibuat oleh subjek dengan IQ tinggi.

Kemampuan komunikasi matematis pada siswa yang memiliki IQ rendah memenuhi semua indikator komunikasi matematis, namun ada beberapa indikator yang tidak 
dipenuhi secara maksimal oleh subjek. Pada indikator pertama, subjek mampu menggambarkan sebuah diagram disertai dengan keterangan untuk melengkapi diagram. Penyajian diagram yang dibuat oleh subjek cukup baik dan mudah dipahami. Selanjutnya pada indikator kedua, subjek mampu menerjemahkan atau menceritakan kembali isi data pada diagram ke dalam bentuk kalimatnya sendiri. Ide ataupun informasi yang dituliskan oleh subjek masih terlalu sedikit sehingga subjek tidak mampu mengembangkan ide yang diperolehnya dari data pada diagram. Pada indikator ketiga, subjek mampu membuat situasi matematika dengan baik melalui keterangan-keterangan yang ditulis saat membuat langkah penyelesaian untuk menggambarkan diagram lingkaran. Langkah-langkah tersebut disusun secara terstruktur mulai dari awal sampai akhir sehingga diperoleh gambar diagram yang mewakili data pada tabel.

Kemampuan komunikasi matematis lisan pada subjek juga menunjukkan bahwa subjek mampu memenuhi hampir seluruh indikator. Pada indikator pertama, subjek mampu memberikan sejumlah informasi dan situasi yang terdapat pada diagram ke dalam bentuk bahasanya sendiri. Subjek menyampaikan informasi yang diperolehnya secara singkat dan hanya berupa informasi yang terlihat langsung pada diagram, namun subjek mampu menyusun informasi tersebut secara terstruktur. Selanjutnya pada indikator kedua, subjek mampu memberikan pendapatnya mengenai konsep penggunaan diagram namun pendapat tersebut masih kurang tepat. Namun saat diminta untuk memberi pendapat lain mengenai penurunan grafik pada diagram, subjek mampu memberikan pendapatnya dengan cukup baik, walaupun dalam penyampaiannya masih terlalu kaku dan tidak tepat dalam melakukan pemilihan kata. Selain itu, subjek juga mampu memberikan saran untuk melengkapi diagram pada soal. Subjek mengemukakan idenya mengenai beberapa keterangan yang perlu ditambahkan pada diagram sehingga menghasilkan diagram yang lengkap dan lebih jelas daripada sebelumnya. Indikator ketiga pada kemampuan komunikasi lisan tidak dipenuhi dengan baik oleh subjek. Hal ini dikarenakan subjek tidak mampu merespon pertanyaan dengan baik saat menyampaikan jawaban. Pada saat merespon jawaban, tampak bahwa subjek tidak begitu yakin dalam menyampaikan jawabannya. Selain itu jawaban yang diberikan subjek juga kurang tepat dan terlalu singkat sehingga tidak mampu memberikan pernyataan lain. Kemudian saat peneliti meminta subjek untuk memberikan kesimpulan di akhir wawancara, subjek mampu memberi kesimpulan yang disusun dengan baik dalam suatu argumen yang meyakinkan. Namun terdapat sedikit kekurangan yaitu kesimpulan yang disampaikan oleh subjek dengan IQ rendah cenderung lebih singkat jika dibandingkan dengan kesimpulan yang dibuat oleh subjek dengan IQ tinggi dan IQ sedang. 


\section{SIMPULAN DAN SARAN}

Berdasarkan hasil penelitian dan pembahasan mengenai kemampuan komunikasi matematis tertulis dan kemampuan komunikasi lisan siswa dengan IQ tinggi, sedang, dan rendah kelas XI SMA Negeri 6 Surakarta diperoleh kesimpulan sebagai berikut: (1) Siswa dengan IQ tinggi memiliki kemampuan komunikasi matematis pada masingmasing aspek sebagai berikut: (a) Pada kemampuan komunikasi matematis tertulis, siswa mampu membuat situasi dan solusi yang tepat dengan menggambarkan diagram; menerjemahkan ide yang terdapat pada diagram ke dalam bentuk kalimatnya sendiri; memberikan sejumlah informasi yang rinci dan terstruktur; dan mampu menyatakan ide dan pendapatnya disertai alasan yang tepat. (b) Pada kemampuan komunikasi matematis lisan, siswa mampu memberikan sejumlah informasi dan situasi yang terdapat pada diagram ke dalam bentuk bahasanya sendiri; mampu mengemukakan pendapat yang tepat untuk menjawab pertanyaan, namun siswa tidak memberikan saran yang diperlukan untuk melengkapi soal; mampu merespon pertanyaan dengan memberikan pendapatnya dalam bentuk argumen yang meyakinkan; dan mampu membuat kesimpulan yang benar dengan penyampaian yang tegas. (2) Siswa dengan IQ sedang memiliki kemampuan komunikasi matematis pada masing-masing aspek sebagai berikut: (a) Pada kemampuan komunikasi matematis tertulis, siswa mampu membuat situasi dan solusi yang tepat dengan menggambarkan diagram dan menambahkan beberapa keterangan yang lengkap; menerjemahkan ide yang terdapat pada diagram ke dalam bentuk kalimatnya sendiri yang disusun secara terstruktur; memberikan beberapa informasi, ide dan keterangan berkaitan dengan data yang tersaji pada diagram; memberikan pendapat secara singkat untuk memberikan alasan. (b) Pada kemampuan komunikasi matematis lisan, siswa mampu memberikan sejumlah informasi dan situasi yang terdapat pada diagram ke dalam bentuk bahasanya sendiri secara rinci, lengkap, dan terstruktur; mampu memberikan pendapat secara tegas dan meyakinkan; mampu memberi saran untuk melengkapi soal; mampu merespon pertanyaan dengan memberikan pendapatnya dalam bentuk argumen yang meyakinkan secara tegas dan jelas; mampu membuat kesimpulan yang benar namun singkat secara tegas. (3) Siswa dengan IQ rendah memiliki kemampuan komunikasi matematis pada masing-masing aspek sebagai berikut: (a) Pada kemampuan komunikasi matematis tertulis, siswa mampu membuat situasi dan solusi yang tepat dengan menggambarkan diagram dan menambahkan beberapa keterangan; mampu menerjemahkan informasi yang terdapat pada diagram ke dalam bentuk kalimatnya sendiri disertai ide dan keterangan yang berkaitan dengan soal. (b) Pada kemampuan komunikasi matematis lisan, siswa mampu memberikan sejumlah informasi dan situasi yang terdapat pada diagram ke dalam bentuk bahasanya sendiri namun informasi tersebut 
masih terlalu singkat; mampu mengemukakan pendapatnya namun masih ada jawaban yang kurang tepat; mampu memberi saran untuk melengkapi soal; tidak mampu merespon pertanyaan dengan baik saat menyampaikan jawaban; dan mampu membuat beberapa kesimpulan yang singkat dengan argumen yang meyakinkan.

Berdasarkan hal tersebut, peneliti memberikan beberapa saran agar sebelum melakukan proses pembelajaran, guru sebaiknya mengetahui IQ masing-masing siswa agar dapat diterapkan solusi belajar yang tepat. Guru sebaiknya membuat suatu kelompok yang menggabungkan siswa IQ sedang dengan siswa IQ rendah pada proses pembelajaran dan memberikan kesempatan kepada siswa untuk memberikan penjelasan di depan kelas. Siswa dengan IQ tinggi sebaiknya lebih sering diberikan soal-soal berupa pertanyaan yang membutuhkan jawaban panjang yang disertai penjelasan dan keterangan. Pada saat proses pembelajaran, guru harus memberikan penjelasan yang spesifik terhadap konsep ataupun istilah-istilah yang digunakan pada materi pelajaran matematika.

\section{DAFTAR PUSTAKA}

Clark, K. K. 2005. Strategies for Building Mathematical Communication in the Middle School Classroom: Modeled in Professional Development, Implemented in the Classroom. CIME (Current Issues in Middle Level Education), Vol. 11, No. 2, Hlm. 1-12.

Bergqvist, E. And Osterholm, M. 2012. Communicating Mathematics or Mathematical Communication? An Analysis of Competence Frameworks. 36th Conference of the International Group for the Psychology of Mathematics Education, Vol. 2, No. 2, hlm. 67-74.

Depdiknas. 2006. Kurikulum Tingkat Satuan Pendidikan. Jakarta: Depdiknas.

Gusni, S. 2006. Pembelajaran dengan Pendekatan Open Ended untuk Meningkatkan Pemahaman dan Kemampuan Komunikasi Matematik Siswa SMP Jakarta. Tesis Pascasarjana Pendidikan Matematika, Universitas Pendidikan Indonesia. Bandung.

Hirschfeld, K. 2008. Mathematical Communication, Conceptual Understanding, and Students' Attitudes Toward Mathematics. In partial fulfillment of the MAT Degree, University of Nebraska-Lincoln. Nebraska.

Jacobs, P. 2002. Matematika sebagai Komunikasi. Prosiding Konferensi Nasional Matematika XI. Universitas Negeri Malang: 22 - 25 Juli 2002.

Jupri, A., Yulianti, K., Rukmana, K., dan Saputra, C. 2007. Pengembangan Desain Pembelajaran Matematika Realistik Untuk Menumbuhkembangkan Kemampuan Pemecahan Masalah dan Komunikasi Matematis Siswa Kelas VII H SMP 22 Bandung. Bandung: Laporan Penelitian. Tidak Dipublikasikan.

Kosko, K.W. and Wilskins, J.L.M. 2010. Mathematical Communication and Its Relation to the Frequency of Manipulative Use. International Electronic Journal of Mathematics Education (IEJME), Vol. 5, No. 2, hlm. 79-90. 
National Council of Teachers of Mathematics (NTCM). 2000. Principles and Standard for School Mathematics. Virginia: NTCM inc.

Pratiwi, D. D. 2013. Kemampuan Komunikasi Matematis dalam Pemecahan Masalah Matematika Sesuai dengan Gaya Kognitif pada Siswa Kelas IX SMP Negeri 1 Surakarta. Tesis Pascasarjana Pendidikan Matematika, UNS. Surakarta.

Qohar, A. 2013. Pengembangan Instrumen Komunikasi Matematis untuk Siswa SMP. Lomba dan Seminar Matematika (LSM) XIX. ISBN : 978-979-17763-3-2, hlm. 45-54.

Suparlan, A. 2013. Eksperimentasi Pembelajaran Kooperatif Tipe NHT dan Tipe TSTS pada Pembelajaran Matematika Ditinjau dari Intelligence Quotient Siswa. Tesis Pascasarjana Pendidikan Matematika, UNS. Surakarta. 